\title{
Thermodynamic Study on the Acid-Base Properties of Antioxidant Compound Ascorbic Acid in Different $\mathrm{NaClO}_{4}$ Aqueous Ethanol Solutions
}

\author{
Morteza Jabbari* and Sedigheh Khosravinia \\ School of Chemistry, Damghan University, 36716-41167 Damghan, Iran
}

\begin{abstract}
The proton dissociation equilibria of ascorbic acid were investigated using a combination of spectrophotometric/potentiometric techniques at constant temperature $25.0 \pm 0.1^{\circ} \mathrm{C}$. The study was carried out over a wide range of ionic strengths of $0.1-3.0 \mathrm{~mol} \mathrm{dm}^{-3} \mathrm{NaClO}_{4}$ in ethanol-water mixture (1:1). The Gran's method was used for glass electrode calibration to obtain $\mathrm{pH}$ readings based on the concentration scale $\left(\mathrm{p}_{\mathrm{c}} \mathrm{H}\right)$. Data process for calculation of the protonation constants was done using the STAR (stability constants by absorbance reading) computer program. The dependence on ionic strength of the constants was analyzed by means of the SIT approach (specific ion interaction theory). In addition to the specific interaction parameters of the ionic species, the protonation constants at infinite dilution (zero ionic strength) were obtained. Finally, the thermodynamic functions $\Delta \mathrm{G}^{0}$ (standard Gibbs free energy change) for the protonation processes were also calculated at different ionic strengths.
\end{abstract}

Keywords: acid-base equilibria, ascorbic acid, ionic strength effect, SIT approach, $\mathrm{NaClO}_{4}$ non-aqueous solution

\section{Introduction}

Ascorbic acid is a well-known essential vitamin (vitamin C) of vital importance for maintenance of human health. It is not synthesized in organisms but is received with food as dissolved in water, and is active in a great number of biochemical processes. ${ }^{1}$ Two of its major interactions are in potentiating the immune system and aiding the synthesis of the protein collagen, which is a fundamental substance that holds together the human body. ${ }^{2}$ It is available at high levels in citrus fruits, green and red peppers, strawberries, tomatoes, turnip and other leafy vegetables. This substance is very sensitive to moisture, light, heat, metal ions and is readily and irreversibly oxidized, especially in aqueous solutions, by reacting with air oxygen such that can be easily transformed into biologically inactive or harmful products. This behavior can limit its uses efficiently. The ability of ascorbic acid to donate electrons makes it a potent water-soluble antioxidant that readily scavenges physiologically relevant reactive species such as molecular oxygen, superoxide, hydroxyl radical, ozone and hypochlorous acid. Therefore, it can prevent chronic diseases due to oxidative stress, including cancer, hypertension, cardiovascular disease and stroke. ${ }^{3-5}$

*e-mail: m_jabari@du.ac.ir
An accurate knowledge about the acid-base properties of bioactive and pharmacopoeia compounds is very important in many fields, since provide basic data to predict the extent of ionization of them as a function of $\mathrm{pH}$ and thus help in understanding the action mechanism of these substances in both chemical and biological processes. Moreover, these information are essential for the measurements of $\mathrm{pH}$-dependent pharmacologic properties such as lipophilicity, permeability, protein binding and solubility which in turn directly affects pharmacokinetic characteristics like absorption, distribution, metabolism, and excretion. ${ }^{6,7}$

Using a combination of $\mathrm{pH}$-metric titration and multiwavelength spectrophotometric method is an accurate and good-reproducibility technique for dissociation constants $\left(\mathrm{pK}_{\mathrm{a}}\right.$ values) determination of each compound that possesses $\mathrm{pH}$-dependent light absorption due to the presence of a chromophore in proximity to the ionization center(s). For instance, the protonated and deprotonated forms exhibit sufficient spectral dissimilarities. In this technique, low analyte concentration is used (about $10^{-5}$ to $10^{-6} \mathrm{~mol} \mathrm{dm}^{-3}$ ) and allows suitable absorbance measurement for products sparingly soluble in water. ${ }^{8}$

While the biological significance of the natural antioxidant compound ascorbic acid is evident, the information related to its acid-base equilibria is relatively 
few in the literature, in particular in non-aqueous media with high ionic strengths. In continuation of our previous investigations, ${ }^{9-12}$ therefore, this work deals with study of the protonation process of ascorbic acid by a UV/pH titration method in different aqueous ethanol solutions (1:1) of $\mathrm{NaClO}_{4}\left(0.1-3.0 \mathrm{~mol} \mathrm{dm}^{-3}\right)$ as background electrolyte. Then, the dependence of acid dissociation equilibria on ionic strength of medium were modeled by the specific ion interaction theory (SIT).

\section{Experimental}

\section{Reagents and chemicals}

Ascorbic acid $\left(\mathrm{C}_{6} \mathrm{H}_{8} \mathrm{O}_{6}\right.$, Scheme 1) was purchased from Sigma as analytical reagent grade material and was used without further purification. The sodium hydroxide and hydrochloric acid solutions (Titrisol, $1.00 \mathrm{~mol} \mathrm{dm}^{-3}$ ) were prepared from Merck. Sodium perchlorate supplied from Merck and was kept at room temperature in vacuum at least 72 hours before use. The organic solvent, ethanol was of analytical grade, obtained from Merck. All dilute solutions were prepared by mixing doubly distilled water, the average resistance of which did not exceed less than $18 \mathrm{M} \Omega \mathrm{cm}$.

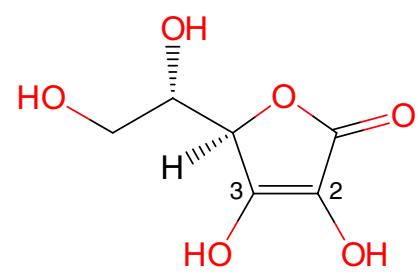

Scheme 1. Chemical structure of ascorbic acid molecule.

\section{Apparatus and procedure}

The potential values of the potentiometric cell, $\mathrm{E}_{\text {cell }}$, were measured using a WTW inoLab (model 720) research $\mathrm{pH}$ meter, equipped with a combined glass-pH electrode (model N 6000 A). The electrode potential can be read with a precision typically of the order of $\pm 0.1 \mathrm{mV}$. The glass electrode was stored in water when not in use and soaked for 10 to $15 \mathrm{~min}$ in the ethanol-water mixture $(1: 1)$ prior to the potentiometric measurements. All titrations were carried out in an $80 \mathrm{~mL}$ thermostatted commercial double-walled glass vessel and the test solution was stirred magnetically for homogenizing it. During the course of titrations, to exclude any atmospheric $\mathrm{CO}_{2}(\mathrm{~g})$ and $\mathrm{O}_{2}(\mathrm{~g})$ trace from the system, a stream of purified $\mathrm{N}_{2}(\mathrm{~g})$ was passed through a sodium hydroxide solution and then bubbled slowly into the working solutions. Absorbance spectra of species in different steps of the titration were recorded on a PerkinElmer (model LAMBDA 25) diode array UV-Vis spectrophotometer in conjunction with a LabTech LCB-R08 thermo-circulator, using quartz cells of path $10 \mathrm{~mm}$.

All experiments related to measuring the $\mathrm{pK}_{\mathrm{a}}$ values of ascorbic acid were done at constant temperature $25.0 \pm 0.1{ }^{\circ} \mathrm{C}$ and ionic strengths of $0.1,0.5,1.0,2.0$ and $3.0 \mathrm{~mol} \mathrm{dm} \mathrm{daClO}_{4}$. The protonation constants were evaluated from the measurements of absorbance versus $\mathrm{E}_{\text {cell }}$ by titration of a known volume of ascorbic acid $\left(4.83 \times 10^{-5} \mathrm{~mol} \mathrm{dm}^{-3}\right)$ with $0.20 \mathrm{~mol} \mathrm{dm}^{-3} \mathrm{NaOH}$ solution both with the same ionic strength and solvent composition. The working solutions were prepared freshly for each experiment, and the container was covered with foil to protect the solution from light.

Before multi-wavelength spectrophotometric titration, first, the glass electrode system calibration was carried out in ionic strengths examined according to the Gran's method. ${ }^{13}$ For this purpose, a measured amount of strong acid solution $\left(20 \mathrm{~mL}\right.$ of $0.01 \mathrm{~mol} \mathrm{dm}^{-3} \mathrm{HCl}$ ) was placed in the double-wall glass vessel. The electrode was immersed in the solution into the titration vessel and then acidic solution was titrated potentiometrically with a strong base $\left(0.20 \mathrm{~mol} \mathrm{dm}^{-3} \mathrm{NaOH}\right)$ both at the same conditions of temperature, ionic strength and solvent composition to be used in later experiments. Sufficient time (normally 2-3 min) was allowed to reach a reasonably stable $\mathrm{E}_{\text {cell }}$ reading before the next titrant addition and the recorded $\mathrm{E}_{\text {cell }}$ values were then used to obtain calibration constants. Usually, 10 or 12 additions of sodium hydroxide solution were enough for these constants to be accurately determined. In the next step, a suitable volume $(0.2 \mathrm{~mL})$ of stock solution of ascorbic acid $\left(0.005 \mathrm{~mol} \mathrm{dm}^{-3}\right)$ was added to the pre-titrated background solution. By continuing the titration, in each addition of titrant, after waiting for the potential reading to be stable, an absorbance spectrum was recorded with $1 \mathrm{~nm}$ resolution at the wavelength range of $\lambda=200-320 \mathrm{~nm}$. Then, all relevant data were stored in computer and a new volume of titrant was added to restart the cycle. Each set of experiments (in different ionic strengths studied), including calibration of the glass electrode and the UV-Vis spectrometric titrations was at least twice repeated under carefully controlled experimental conditions. Typically, the experimental values of $\mathrm{E}_{\text {cell }}$ as a function of the added volume of alkaline titrant for the combined glass electrode calibration and potentiometric titration are listed in Table 1 in $1.0 \mathrm{~mol} \mathrm{dm}^{-3} \mathrm{NaClO}_{4}$ ionic strength.

The typical potentiometric titration curves (a plot of $\mathrm{pH}$ or $\mathrm{E}_{\text {cell }}$ against $\mathrm{V}$ ) for ascorbic acid at ionic strength of $1.0 \mathrm{~mol} \mathrm{dm}^{-3} \mathrm{NaClO}_{4}$ medium, $25.0^{\circ} \mathrm{C}$ and $50 \%$ ethanol (v/v) are shown in Figure 1. Ascorbic acid is a lactone with a 
Table 1. The experimental values of cell potential, $\mathrm{E}_{\mathrm{cell}}$, as a function of the added volume of sodium hydroxide, $\mathrm{V}_{\mathrm{NaOH}}$, for the combined glass electrode calibration and protonation titration of ascorbic acid at $25.0{ }^{\circ} \mathrm{C}$ and $1.0 \mathrm{~mol} \mathrm{dm}^{-3}$ aqueous ethanol mixture (1:1) of $\mathrm{NaClO}_{4}$

\begin{tabular}{|c|c|c|c|c|c|c|c|}
\hline \multicolumn{8}{|c|}{ Combined glass electrode calibration titration $^{\mathrm{a}}$} \\
\hline$\underline{\mathrm{V}^{\mathrm{b}} / \mathrm{mL}}$ & $\mathrm{E}^{\mathrm{c}} / \mathrm{mL}$ & $\mathrm{V}^{\mathrm{b}} / \mathrm{mL}$ & $\mathrm{E}^{\mathrm{c}} / \mathrm{mL}$ & $\mathrm{V}^{\mathrm{b}} / \mathrm{mL}$ & $\mathrm{E}^{\mathrm{c}} / \mathrm{mL}$ & $\mathrm{V}^{\mathrm{b}} / \mathrm{mL}$ & $\mathrm{E}^{\mathrm{c}} / \mathrm{mL}$ \\
\hline 0.00 & 268.0 & 0.15 & 265.3 & 0.30 & 262.3 & 0.45 & 259.1 \\
\hline 0.05 & 267.1 & 0.20 & 264.3 & 0.35 & 261.3 & 0.50 & 258.0 \\
\hline 0.10 & 266.3 & 0.25 & 263.3 & 0.40 & 260.2 & & \\
\hline \multicolumn{8}{|c|}{ Protonation titration $^{\mathrm{d}}$} \\
\hline 0.000 & 257.2 & 1.3060 & 135.3 & 1.3259 & -33.5 & 1.5039 & -243.3 \\
\hline 0.300 & 250.0 & 1.3100 & 129.2 & 1.3299 & -62.8 & 1.6039 & -254.8 \\
\hline 0.700 & 234.4 & 1.3150 & 110.2 & 1.3329 & -75.7 & 1.8039 & -268.9 \\
\hline 0.900 & 223.3 & 1.3180 & 99.0 & 1.3374 & -115.7 & 2.1539 & -282.1 \\
\hline 0.980 & 216.3 & 1.3200 & 84.3 & 1.3409 & -134.1 & 2.7539 & -293.6 \\
\hline 1.020 & 212.2 & 1.3213 & 56.0 & 1.3449 & -146.1 & 3.5539 & -302.1 \\
\hline 1.080 & 203.9 & 1.3219 & 36.4 & 1.3499 & -163.0 & 4.5539 & -308.3 \\
\hline 1.135 & 192.7 & 1.3222 & 15.1 & 1.3559 & -169.6 & 6.5539 & -314.7 \\
\hline 1.175 & 180.8 & 1.3223 & 2.5 & 1.3639 & -183.8 & 9.0539 & -319.8 \\
\hline 1.203 & 168.3 & 1.3225 & -4.3 & 1.3739 & -189.3 & & \\
\hline 1.220 & 156.9 & 1.3229 & -8.5 & 1.3989 & -211.0 & & \\
\hline 1.300 & 148.1 & 1.3239 & -22.3 & 1.4389 & -227.7 & & \\
\hline
\end{tabular}

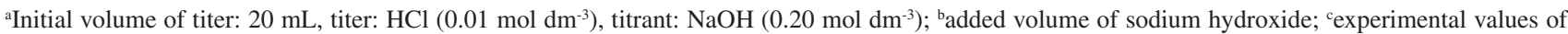

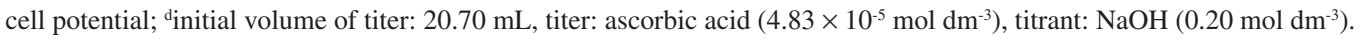

2,3-endiol group (Scheme 1). The enolic group imparts acidity to the molecule which is at positions 2 and 3 . The first step was clearly observed in the potentiometric curve (Figure 1) which relating to the enol group at position 3
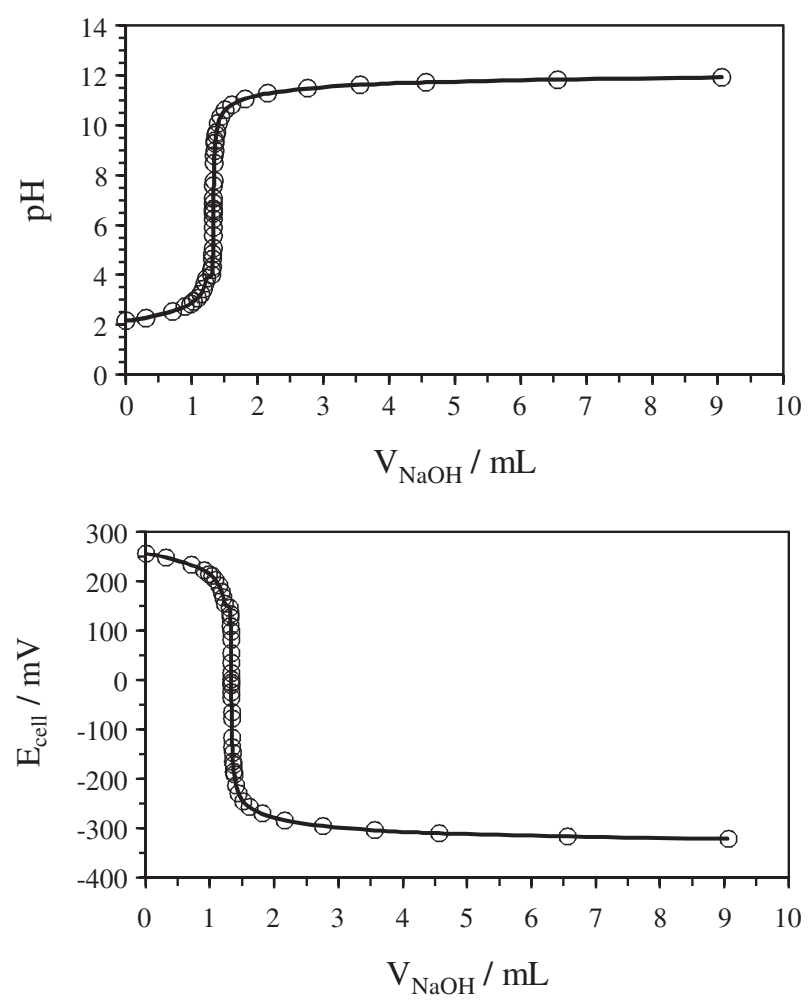

Figure 1. Plots of potentiometric titration of $4.83 \times 10^{-5} \mathrm{~mol} \mathrm{dm}^{-3}$ ascorbic acid with $0.20 \mathrm{~mol} \mathrm{dm}^{-3} \mathrm{NaOH}$ at ionic strength of $1.0 \mathrm{~mol} \mathrm{dm}^{-3} \mathrm{NaClO}_{4}$ medium and $25.0^{\circ} \mathrm{C}$. (the meta position to the carbonyl group). The second step was not clearly seen as expected and it is related to the enol group at position orto to carbonyl (position 2). ${ }^{3}$ In addition, Figure 2 shows the electronic spectral changes of ascorbic acid in the $\mathrm{pH}$ range 2.0-12.0 at ionic strength of $1.0 \mathrm{~mol} \mathrm{dm}^{-3} \mathrm{NaClO}_{4}$. When an alkali solution was added to the acidic aqueous solution of ascorbic acid, the absorption spectrum is shifted to upper wavelengths with an important modification. Such that the absorption band at $245 \mathrm{~nm}$ progressively decreases to lower values by increasing $\mathrm{pH}$ with a concomitant appearance of a new peak at $265 \mathrm{~nm}$ which gradually increased from $\mathrm{pH}$ ca. 2 to its highest intensity at alkaline $\mathrm{pH}$. The notable changes in the absorption spectrum of ascorbic acid as a function of $\mathrm{pH}$ are attributed to the formation of various protonated species whose light absorbing characteristics differ from each other.

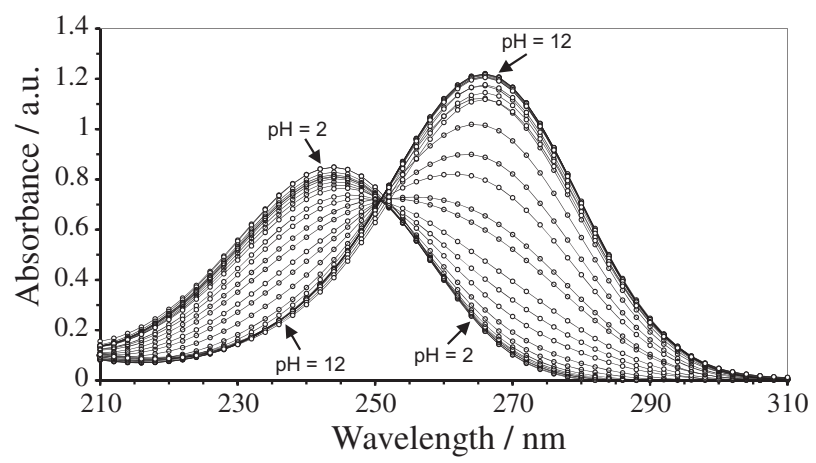

Figure 2. The absorbance spectrum changes of ascorbic acid in the $\mathrm{pH}$ ranges 2.0-12.0 at ionic strength of $1.0 \mathrm{~mol} \mathrm{dm}^{-3} \mathrm{NaClO}_{4}$ medium and $25.0^{\circ} \mathrm{C}$ 
The protonation constants of ascorbic acid were calculated by processing the UV-Vis spectrophotometric titrations data using the computer program STAR (stability constants by absorbance reading). The STAR program uses multi-linear regression for the refinement of equilibrium constants of systems with up to 5 components, which form up to 25 species. ${ }^{14}$ It can work with up to 50 different spectra, measured at 50 different wavelengths. In this program, the refinement of equilibrium constants is done using the Gauss-Newton non-linear least-squares algorithm, until a minimum value in the sum of squares residuals (SSR) between the calculated and the experimental data of the spectrophotometric titration spectra is obtained with equation 1:

$\operatorname{SSR}=\sum_{i=1}^{n_{s}} \sum_{j=1}^{n_{W}}\left(A_{i, j, e x p}-A_{i, j, c a l}\right)^{2}$

where $n_{s}$ and $n_{w}$ are the number of solutions and the number of wavelengths, respectively. $\mathrm{A}_{\mathrm{i}, \mathrm{j}, \mathrm{exp}}$ and $\mathrm{A}_{\mathrm{i}, \mathrm{j}, \mathrm{cal}}$ are the experimental and calculated absorbance values for the wavelength $\mathrm{j}$ in the spectrum $\mathrm{i}$. The values of $\mathrm{A}_{\text {cal }}$ are obtained in three steps: the program first solves the mass balances for each spectrum according to the guessed equilibrium constants and experimental conditions; then, a multiple linear regression procedure is applied in order to determine the molar absorbances of each unknown species, and finally the individual absorbance values are re-calculated from the guessed species concentration and the corresponding molar absorbances. The minimization process was repeated until the relative change of RSS between two iterations is less than $0.01 \% .^{15}$

\section{Results and Discussion}

\section{Calibration of glass electrode cell}

Prior to each UV-Vis spectrophotometric titration, the potentiometric cell was calibrated to evaluate the $\mathrm{pH}$ of the solution based on the concentration scale from calibration constants obtained at each of ionic strengths tested. The calibration constants were computed from the Nernst equation knowing the exact concentration of $\mathrm{H}^{+}$in each titration point. ${ }^{16}$ According to the Nernst equation, the potential of a potentiometric cell equipped by a glass electrode can be written as equation 2 :

$\mathrm{E}_{\text {cell }}=\mathrm{E}_{\text {cell }}^{\circ}+\mathrm{k}\left(\log \left[\mathrm{H}^{+}\right]+\log \gamma_{\mathrm{H}+}\right)+\mathrm{E}_{\mathrm{LJ}}$

where $\mathrm{E}_{\mathrm{LJ}}$ is the liquid junction potential, $\mathrm{k}$ (the Nernstian slope $)=2.303 \mathrm{RT} / \mathrm{F}$ in which $\mathrm{R}, \mathrm{T}$ and $\mathrm{F}$ are the universal gas constant, the absolute temperature and the Faraday constant, respectively. $\gamma_{\mathrm{H}+}$ is the activity coefficient of hydrogen ion. Because the ionic strength of the solution is kept constant for each experiment, the activity coefficient of hydrogen ion is constant too. The non-ideality of solutions is then included in $\mathrm{E}_{\mathrm{a}}$ (the pseudo-Nernstian standard potential), and thus:

$\mathrm{E}_{\text {cell }}=\mathrm{E}_{\mathrm{a}}+\mathrm{k} \log \left[\mathrm{H}^{+}\right]$

where $\mathrm{E}_{\mathrm{a}}$ being $\mathrm{E}_{\text {cell }}^{\circ}+\mathrm{klog} \gamma_{\mathrm{H}+}+\mathrm{E}_{\mathrm{LJ}}$. The hydrogen ion concentration can be easily calculated by:

$\left[\mathrm{H}^{+}\right]=\left(\mathrm{C}_{\mathrm{HCl}} \mathrm{V}_{0}-\mathrm{C}_{\mathrm{NaOH}} \mathrm{V}_{\mathrm{ad}}\right) /\left(\mathrm{V}_{0}+\mathrm{V}_{\mathrm{ad}}\right)$

where $\mathrm{C}_{\mathrm{HCl}}$ and $\mathrm{C}_{\mathrm{NaOH}}$ are the molar concentrations of $\mathrm{HCl}$ and $\mathrm{NaOH}, \mathrm{V}_{0}$ and $\mathrm{V}_{\text {ad }}$ are the initial volume of acidic solution (titer) and the added volume of sodium hydroxide solution (titrant) at each point, respectively. The $\mathrm{E}_{\mathrm{a}}$ values were calculated from the recorded $\mathrm{E}_{\text {cell }}$ and known concentration of solvated proton in every titration point by linear regression analysis. For each experiment at constant ionic strength, the slopes obtained from least squares analysis were close to the theoretical Nernst value $\left(59.167 \mathrm{mV}\right.$ at $\left.25.0^{\circ} \mathrm{C}\right)$ with correlation coefficients greater than 0.99 . The calibration constants $\left(\mathrm{E}_{\mathrm{a}}\right.$ and $\left.\mathrm{k}\right)$ obtained for the combined glass electrode at working mixtures are given in Table 2. The calibration constants were used to correct the recorded values in millivolt $(\mathrm{E})$ during titration into the $\mathrm{pH}$ scale, $\mathrm{pH}=-\log \left[\mathrm{H}^{+}\right]$, as follows:

$\mathrm{pH}=\left(\mathrm{E}_{\mathrm{a}}-\mathrm{E}_{\mathrm{cell}}\right) / \mathrm{k}$

Table 2. The calibration constants obtained for the combined glass $\mathrm{pH}$ electrode in different ionic strengths of $\mathrm{NaClO}_{4}$ aqueous ethanol solution (1:1) at $25.0^{\circ} \mathrm{C}$

\begin{tabular}{lccccc}
\hline $\mathrm{I}^{\mathrm{a}} /\left(\mathrm{mol} \mathrm{kg}^{-1}\right)$ & 0.101 & 0.513 & 1.051 & 2.212 & 3.503 \\
\hline $\mathrm{k}^{\mathrm{b}}$ & 59.78 & 58.99 & 59.07 & 59.42 & 59.92 \\
$\mathrm{E}_{\mathrm{a}}^{\mathrm{c}} / \mathrm{mV}$ & 382.70 & 381.17 & 386.10 & 397.30 & 465.70 \\
\hline & \\
& a: ionic strength; ${ }^{\mathrm{b}} \mathrm{k}$ : the Nernstian slope; ${ }^{\mathrm{c}}$ Ea: pseudo-Nernstian standard \\
potential.
\end{tabular}

As shown in Table 2, the $\mathrm{E}_{\mathrm{a}}$ values increase with increasing the electrolyte concentration used. This is possibly due to the dependence of the activity coefficient of hydrogen ion on ionic strength based on the equation $\mathrm{E}_{\mathrm{a}}=\mathrm{E}_{\text {cell }}^{\circ}+\mathrm{klog} \gamma_{\mathrm{H}+}+\mathrm{E}_{\mathrm{LJ}}$, which parameters are already described.

\section{Calculation of protonation constants}

The $\mathrm{pK}_{\mathrm{a}}$ values of ascorbic acid (in the molal concentration scale) were calculated by the STAR 
Table 3. The $\mathrm{pK}_{\mathrm{a}}$ values of ascorbic acid in different ionic strengths of $\mathrm{NaClO}_{4}$ aqueous ethanol solution $(1: 1)$ at $25.0{ }^{\circ} \mathrm{C}$

\begin{tabular}{lcccccc}
\hline $\mathrm{I}^{\mathrm{a}} /\left(\mathrm{mol} \mathrm{kg}^{-1}\right)$ & $\mathrm{I}^{\mathrm{a}} /\left(\mathrm{mol} \mathrm{kg}^{-1}\right)$ & $\mathrm{pK}_{1}^{\mathrm{b}} /\left(\mathrm{mol} \mathrm{kg}^{-1}\right)$ & $\mathrm{pK}_{2}^{\mathrm{b}} /\left(\mathrm{mol} \mathrm{kg}^{-1}\right)$ & Kurtosis test & Skewness test & Reference \\
\hline 0.1 & 0.101 & $4.39 \pm 0.09^{\mathrm{c}}$ & $12.26 \pm 0.03^{\mathrm{c}}$ & 8.4 & -0.67 & present work \\
0.5 & 0.513 & $4.26 \pm 0.08$ & $11.73 \pm 0.03$ & 5.2 & 0.16 & present work \\
1.0 & 1.051 & $4.19 \pm 0.03$ & $11.48 \pm 0.02$ & 7.1 & 0.6 & present work \\
2.0 & 2.212 & $4.28 \pm 0.07$ & $11.67 \pm 0.03$ & 7.5 & 0.36 & present work \\
3.0 & 3.503 & $4.43 \pm 0.08$ & $12.02 \pm 0.04$ & 6.8 & & present work \\
$0.1 \mathrm{~mol} \mathrm{dm}^{-3}$ in water & & 4.05 & 11.81 & & 17 \\
$0.2 \mathrm{~mol} \mathrm{dm}^{-3}$ in water & & 4.16 & 11.73 & & 18 \\
$1.0 \mathrm{~mol} \mathrm{dm}^{-3}$ in water & & 4.20 & 11.36 & & 3 \\
$3.0 \mathrm{~mol} \mathrm{dm}^{-3}$ in water & & 4.37 & 11.34 & & 19 \\
\hline
\end{tabular}

${ }^{\mathrm{a}} \mathrm{I}$ : ionic strength; ${ }^{\mathrm{b}} \mathrm{K}_{1}$ and $\mathrm{K}_{2}$ refer to the stepwise protonation equilibria of $\mathrm{HA}^{-}$and $\mathrm{A}^{2-}$, respectively (where $\mathrm{A}^{2-}$ represents the fully deprotonated ascorbic acid); ${ }^{\mathrm{c}}$ standard deviation.

computer program in different aqueous ethanol solutions (1:1) of $\mathrm{NaClO}_{4}\left(0.1-3.0 \mathrm{~mol} \mathrm{dm}^{-3}\right)$. The STAR gives a series of statistical characteristics to test the reliability of the fitting process which are valuable when several chemical models are compared for a given system. These statistical parameters include the kurtosis, skewness tests. The kurtosis test is the measure of the peakedness of the error distribution near a model value. For an ideal normal distribution of residuals, kurtosis value should be three. The skewness test shows shape of the error distribution profile and its values should be equal to zero. ${ }^{14}$ The experimental protonation constants of ascorbic acid along with some of the important statistical parameters are listed in Table 3. The dependence of these constants on ionic strength show a regular trend and the $\mathrm{pK}_{\mathrm{a}}$ values (Table 3 ) agree fairly well with findings reported previously in the literature, ${ }^{3,17-19}$ after allowing for changes in experimental conditions as well as methods of calculation. The experimental $\mathrm{pK}_{\mathrm{a}}$ values (Table 3), determined in $\mathrm{NaClO}_{4}$ aqueous ethanol solutions (1:1) with different concentrations are shown as a function of the square root of ionic strength (in mol kg-1) in Figure 3. As it can be seen in this figure, the $\mathrm{pK}_{\mathrm{a}}$ values of ascorbic acid are nearly always at their minimum at an ionic strength range around $0.3-0.9 \mathrm{~mol} \mathrm{~kg}^{-1}$, which is a characteristic of dependence on ionic strength of the protonation constant. According to the electrolyte solutions at low ionic strength, the dependence accounts for the Coulomb interaction between the ions that are screened by the ion atmosphere, while at higher concentrations the dependence accounts for the disturbances in ion-solvent interactions. ${ }^{20,21}$ In other words, at low ionic strength $\left(<0.1 \mathrm{~mol} \mathrm{~kg}^{-1}\right)$ the Coulomb interactions are of primary importance. However, as the ionic strength increases, the ionic atmosphere becomes more compressed and screens the ionic charges more effectively, so the intermolecular interactions (dipole-dipole or even multipole-multipole) become more important. These forces at higher ionic strength possibly have a primary role between the ions.
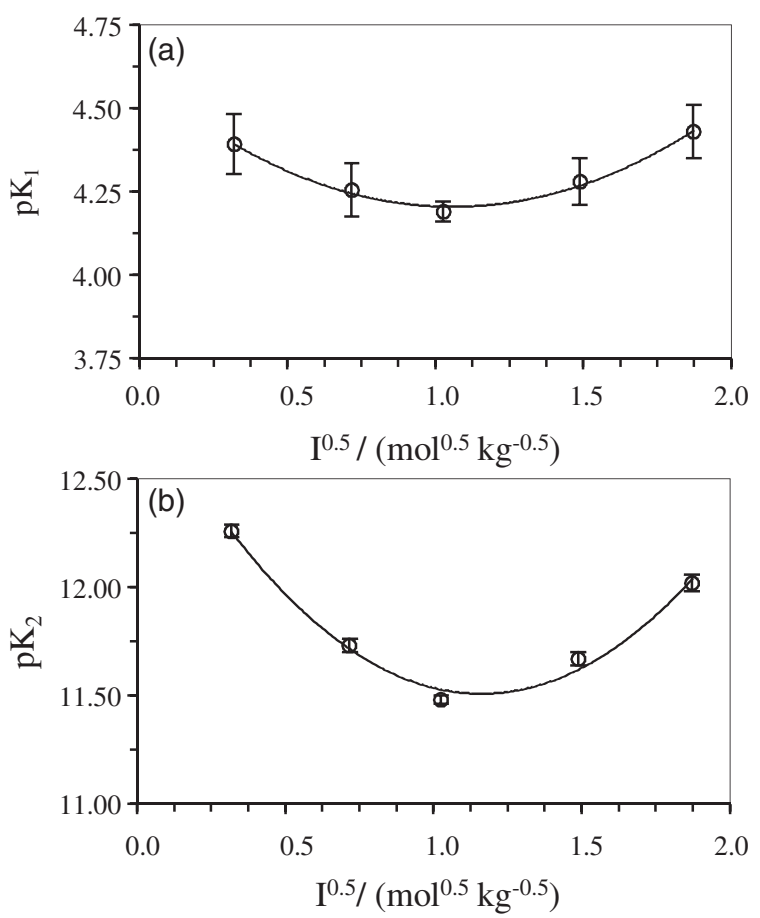

Figure 3. Plots of (a) $\mathrm{pK}_{1}$ and (b) $\mathrm{pK}_{2}$ (in molal scale) of ascorbic acid versus the square root of ionic strength of $\mathrm{NaClO}_{4}$ at $25.0^{\circ} \mathrm{C}$.

In Figure 4 the equilibrium distribution of various species of ascorbic acid in ionic strength of $1.0 \mathrm{~mol} \mathrm{dm}^{-3}$ $\mathrm{NaClO}_{4}$ is shown as a function of $\mathrm{pH}$.

The thermodynamic functions $\Delta \mathrm{G}^{0}$ (standard Gibbs free energy change) associated with the protonation process of ascorbic acid studied have also been calculated in different ionic strengths of $\mathrm{NaClO}_{4}$ according to the following equation: 


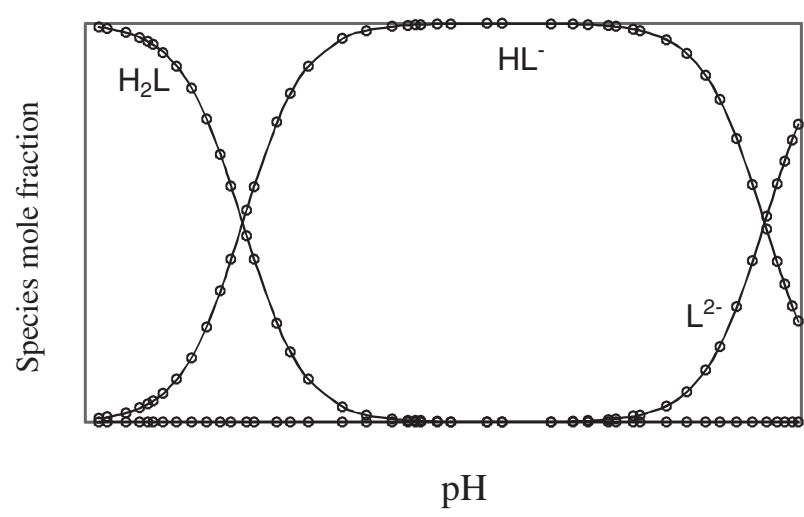

Figure 4. Distribution diagram of the different species of ascorbic acid as a function of $\mathrm{pH}$ at $25.0^{\circ} \mathrm{C}$ and ionic strength $1.0 \mathrm{~mol} \mathrm{dm}^{-3} \mathrm{NaClO}_{4}$.

$\Delta \mathrm{G}^{0}=2.303 \mathrm{RTpK}$

where $\mathrm{R}$ represents the gas constant $\left(8.31451 \mathrm{~J} \mathrm{~K}^{-1} \mathrm{~mol}^{-1}\right)$, $\mathrm{T}$ stands for absolute temperature $(298.15 \mathrm{~K})$, and $\mathrm{pK}_{\mathrm{a}}$ is dissociation constant for the compound studied (Table 3 ). The functions $\Delta \mathrm{G}^{0}$ of ascorbic acid protonation reaction in different ionic strengths $\left(0.1-3.0 \mathrm{~mol} \mathrm{dm}-3 \mathrm{NaClO}_{4}\right)$ are listed in Table 4. Unfortunately, there is no value reported in the literature for comparison. The positive values of $\Delta \mathrm{G}^{0}$ for the proton dissociation processes of ascorbic acid denote that the processes are not spontaneous.

Table 4. The standard Gibbs free energy changes of protonation of ascorbic acid at $25.0{ }^{\circ} \mathrm{C}$ and various ionic strengths of $\mathrm{NaClO}_{4}$ aqueous ethanol solution $(1: 1)$

\begin{tabular}{lcc}
\hline $\mathrm{I}^{\mathrm{a}} /\left(\mathrm{mol} \mathrm{kg}^{-1}\right)$ & $\Delta \mathrm{G}_{1}^{0}{ }^{\mathrm{b}} /\left(\mathrm{kJ} \mathrm{mol}^{-1}\right)$ & $\Delta \mathrm{G}_{2}^{0} \mathrm{~b} /\left(\mathrm{kJ} \mathrm{mol}^{-1}\right)$ \\
\hline 0.101 & 25.08 & 69.99 \\
0.513 & 24.29 & 66.97 \\
1.051 & 23.92 & 65.54 \\
2.212 & 24.43 & 66.62 \\
3.503 & 25.29 & 68.62 \\
\hline
\end{tabular}

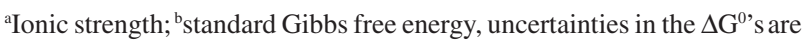
equal to the corresponding $\mathrm{pK}_{\mathrm{a}}$ values.

\section{Modeling of ionic strength effect}

The general stepwise reaction for protonation equilibria can be expressed by:

$$
\mathrm{H}_{\mathrm{n}} \mathrm{A}^{(\mathrm{z}-\mathrm{n})-} \rightleftharpoons \mathrm{H}_{\mathrm{n}-1} \mathrm{~A}^{(\mathrm{z}-\mathrm{n}+1)-}+\mathrm{H}^{+}
$$

where species $\mathrm{H}_{n} \mathrm{~A}(\mathrm{n}=2)$ indicates the full protonated form of ascorbic acid and the charge $\mathrm{z}$ is formally $=2$. A stepwise thermodynamic dissociation constants $K_{n}$ for these equilibria is given by:
$\mathrm{K}_{\mathrm{n}}=\frac{\left[\mathrm{H}^{+}\right]\left[\mathrm{H}_{\mathrm{n}-1} \mathrm{~A}^{(\mathrm{z}-\mathrm{n}+1)-}\right]}{\left[\mathrm{H}_{\mathrm{n}} \mathrm{A}\right]^{(\mathrm{z}-\mathrm{n})-}} \frac{\gamma_{\mathrm{H}^{+}} \gamma_{\mathrm{H}_{\mathrm{n}-\mathrm{A}} \mathrm{A}^{(z-\mathrm{n}+1)-}}}{\gamma_{\mathrm{H}_{\mathrm{n}} \mathrm{A}^{(z-\mathrm{n})-}}}=\mathrm{K}_{\mathrm{n}}^{0} \frac{\gamma_{\mathrm{H}^{+}} \gamma_{\mathrm{H}_{\mathrm{n}-\mathrm{A}} \mathrm{A}^{(z-\mathrm{n}+1)-}}}{\gamma_{\mathrm{H}_{\mathrm{n}} \mathrm{A}^{(z-\mathrm{n})-}}}$

where $\gamma_{i}$ is activity coefficient of species $i$, and $\mathrm{K}_{\mathrm{n}}{ }^{0}$ refer to the protonation constant, expressed as a concentration quotient, at infinite dilution in a particular medium. By taking negative logarithms on equation 8 :

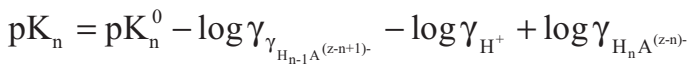

The determination of $\mathrm{pK}_{\mathrm{n}}^{0}$ value requires that the activity coefficient values are known. The activity coefficient of species can be expressed by the specific ion interaction theory (SIT). The SIT model was first outlined by Brönsted and later elaborated by Guggenheim and Scatchard., ${ }^{922-26}$ Due to its simplicity, it can still be considered as one of the most popular prediction strategies in solution chemistry. In original SIT model, activity coefficient of ion i with charge $\mathrm{Z}_{\mathrm{i}}$ can be expressed by equation 10 in the solution of ionic strength $\mathrm{I}_{\mathrm{m}}$ (in molal scale) at $25.0^{\circ} \mathrm{C}$ :

$\log \gamma_{i}=-z_{i}^{2} \frac{A \sqrt{I_{m}}}{1+a B \sqrt{I_{m}}}+\sum_{j} \varepsilon_{i j} m_{j}$

where $\mathrm{A}$ is the Debye-Huckel limiting law slope $\left(0.509 \mathrm{~kg}^{0.5} \mathrm{~mol}^{-0.5}\right), \mathrm{aB}$ is an empirical constant involving the mean distance of closest approach of ions from the Debye-Huckel limiting law $\left(1.5 \mathrm{~kg}^{0.5} \mathrm{~mol}^{-0.5}\right)$. The ion interaction coefficient $\varepsilon_{\mathrm{ij}}$, usually called SIT parameter, interprets the specific short range non-electrostatic interactions of ion $\mathrm{i}^{\text {th }}$ with ion $\mathrm{j}^{\text {th }}$ in its molal concentration $\mathrm{m}_{\mathrm{j}}$. The SIT model assumes that interaction coefficient is zero for two electrically like sign ions or neutral species (this is the Brönsted principle of specific ionic interaction). Although SIT parameters are approximately considered to be constant for some ionic media in $0.500 \leq \mathrm{I}_{\mathrm{m}} \leq 3.500 \mathrm{~mol} \mathrm{~kg}^{-1}$, however literature indicate that they are function of I at lower and higher ionic strength. ${ }^{27}$ An expertise group in Italy modified the SIT model and introduced dependence on ionic strength of $\varepsilon$ as following term: ${ }^{28}$

$\varepsilon=\varepsilon_{\infty}+\frac{\varepsilon_{0}-\varepsilon_{\infty}}{1+\mathrm{I}}$

where $\varepsilon_{0}$ and $\varepsilon_{\infty}$ parameters take into account the dependence of SIT parameters on medium ionic strength and are the values of $\varepsilon$ for $\mathrm{I} \rightarrow 0$ and $\mathrm{I} \rightarrow \infty$, respectively.

By considering the modified SIT model for calculation of activity coefficients of species in $\mathrm{NaClO}_{4}$ as supporting electrolyte, equation 9 can be reformulated as follows: 
Table 5. Results of SIT analysis on $\mathrm{pK}_{\mathrm{a}}$ values of ascorbic acid in different ionic strengths of $\mathrm{NaClO}_{4}$ aqueous ethanol mixture $(1: 1)$ at $25.0{ }^{\circ} \mathrm{C}$

\begin{tabular}{|c|c|c|c|c|c|c|c|c|}
\hline $\mathrm{n}$ & $\mathrm{pK}_{\mathrm{n}}^{0}$ & $\begin{array}{c}\Delta \mathrm{G}^{0}{ }_{\mathrm{on}}{ }^{\mathrm{a}} / \\
\left(\mathrm{kJ} \mathrm{mol}^{-1}\right)\end{array}$ & $\Delta \varepsilon_{0}{ }^{b}$ & $\Delta \varepsilon_{\infty}^{\mathrm{b}}$ & $\varepsilon_{0}^{\mathrm{Na}^{+}, \mathrm{H}_{\mathrm{n}-1} \mathrm{~L}^{(2-\mathrm{n}+1)-\mathrm{c}}}$ & $\varepsilon_{\infty}^{\mathrm{Na}^{+}, \mathrm{H}_{\mathrm{n}-1} \mathrm{~L}^{(2-n+1)-\mathrm{c}}}$ & $\sigma_{\text {fit }}{ }^{d}$ & $\mathrm{r}^{2 \mathrm{e}}$ \\
\hline 1 & $4.64 \pm 0.02$ & 26.47 & -0.219 & 0.171 & -0.281 & 0.004 & 0.0004 & 0.988 \\
\hline 2 & $12.83 \pm 0.03$ & 73.24 & -1.467 & 0.496 & -1.811 & 0.332 & 0.003 & 0.991 \\
\hline
\end{tabular}

${ }^{a}$ Standard Gibbs free energy; ${ }^{b}$ the difference of specific coefficients; 'specific interaction coefficient of ions; ${ }^{\mathrm{d}}$ values of the error least-square sum on the

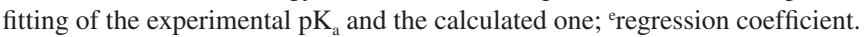

$\mathrm{pK}_{\mathrm{n}}=\mathrm{pK}_{\mathrm{n}}^{0}+\mathrm{z}^{*} \frac{\mathrm{A} \sqrt{\mathrm{I}_{\mathrm{m}}}}{1+\mathrm{aB} \sqrt{\mathrm{I}_{\mathrm{m}}}}-\Delta \varepsilon \mathrm{I}_{\mathrm{m}}$

where

$\mathrm{z}^{*}=\sum(\text { charges })_{\text {products }}^{2}-\sum(\text { charges })_{\text {reactants }}^{2}$

$\Delta \varepsilon=\varepsilon_{\mathrm{H}_{\mathrm{n}-1} \mathrm{~A}^{(2 \mathrm{n}-\mathrm{n}+1)}, \mathrm{Na}^{+}}+\varepsilon_{\mathrm{H}^{+}, \mathrm{ClO}_{4}^{-}}-\varepsilon_{\mathrm{H}_{\mathrm{n}} \mathrm{A}^{(2 \mathrm{n}) \mathrm{n},}, \mathrm{Na}^{+}}$

It should be noted that $\mathrm{pK}_{\mathrm{a}}$ and $\mathrm{I}_{\mathrm{m}}$ values are in molal

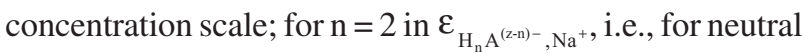
full protonated ascorbic acid, $\varepsilon$ was considered zero, also all SIT interaction coefficients were defined ionic strength dependency by using equation 11 .

Experimental $\mathrm{pK}_{\mathrm{a}}$ values listed in Table 3 were fitted into equation 12 as a function of ionic strength by least-squares regression analysis. The results of the SIT calculations of our data are given in Table 5. The goodness of fit of SIT model was judged by the square correlation coefficient, associated with values of the error least-square sum on the fitting of the experimental $\mathrm{pK}_{\mathrm{a}}$ and the calculated one $\left(\sigma_{\mathrm{fit}}\right)$. Ion interaction coefficients of $\varepsilon_{0}^{\mathrm{Na}^{+}, \mathrm{H}_{\mathrm{n}-1} \mathrm{~A}^{(z-n+1)-}}$ and $\varepsilon_{\infty}^{\mathrm{Na}^{+}, \mathrm{H}_{\mathrm{n}-1} \mathrm{~A}^{(2-\mathrm{n}+1)-}}$ were calculated according to values of SIT parameters of $\mathrm{HClO}_{4}\left(\varepsilon_{0}^{\mathrm{H}^{+}, \mathrm{ClO}_{4}^{-}}=0.062\right.$ and $\left.\varepsilon_{\infty}^{\mathrm{H}^{+}, \mathrm{ClO}_{4}^{-}}=0.167\right)$ reported in literature. ${ }^{28}$ In addition, the values of $\Delta \mathrm{G}_{0}{ }^{0}$ (standard Gibbs free energy change at infinite dilution) for protonation of ascorbic acid are calculated based on $\mathrm{pK}_{\mathrm{n}}^{0}$ obtained from SIT model by equation 6 and are given in Table 5 .

As shown in Table 5, the $\varepsilon$ interaction coefficients of the $\mathrm{Na}^{+}$cation with deprotonated ascorbic acid species for first protonation step are lower than those obtained in second step. Such trend for the interaction coefficients can be explained by taking into account this fact which the greater $\varepsilon$ possibly causes the stronger interaction of the species, and hence a greater protonation constant in the supporting electrolyte. This result is also observed from concavity of the curves given in Figure 3.

\section{Conclusions}

The dissociation equilibria of biological compound ascorbic acid were investigated by a combination of $\mathrm{UV} / \mathrm{pH}$ titration methods in a wide range of ionic strength supplied by sodium perchlorate $\left(0.1-3.0 \mathrm{~mol} \mathrm{dm}^{-3}\right)$ at temperature $25.0 \pm 0.1{ }^{\circ} \mathrm{C}$. Organic co-solvent $(50 \%$ ethanol) together water has been used as a reaction medium for this investigation. The $\mathrm{pK}_{\mathrm{a}}$ values were calculated by multivariate curve fitting of spectral data implemented in STAR program. The results show that the $\mathrm{pK}_{\mathrm{a}}$ values of ascorbic acid are influenced by the ionic strength of medium. The SIT approach was applied successfully to model the ionic strength dependence of $\mathrm{pK}_{\mathrm{a}}$ values. As a matter of fact, the information about the proton dissociation is important and widely useful. For instance, the first $\mathrm{pK}_{\mathrm{a}}$ value of ascorbic acid is around 4.0, the anions derived from proton dissociation will dominate in natural system (occurrence $>99.5 \%$ ). Therefore, ascorbic acid as a phenolic antioxidant $(\mathrm{ArOH})$, may exert its antioxidant activity (free radical scavenging role) via $\mathrm{H}$-atom donation mechanism in acidic solution while the same activity is done by means of electron donation mechanism in natural and alkaline media.

\section{Acknowledgments}

The authors gratefully acknowledge the Damghan University for facilitating the equipment and laboratories used.

\section{References}

1. Demianenko, E.; Ilchenko, M.; Grebenyuk, A.; Lobanov, V.; Tsendra, O.; J. Mol. Model. 2014, 20, 2128.

2. Dimitrova, Y.; Spectrochim. Acta, Part A 2006, 63, 427.

3. Thakur, U. K.; Shah, D. J.; Sawant, R. M.; Ramakumar, K. L.; J. Chem. Eng. Data 2010, 55, 308.

4. Jaiswal, P. V.; Ijeri, V. S.; Srivastava, A. K.; Colloids Surf., B 2005, 46, 45 .

5. Kurl, S.; Tuomainen, T. P.; Laukkanen, J. A.; Nyyssonen, L. T.; Sivenius, J.; Salonen, J. T.; Stroke 2002, 33, 1568.

6. Chan, J.; Vogel, S. M.; Wen, J.; Alany, R. G.; J. Pharm. Biomed. Anal. 2009, 50, 86.

7. Sanli, S.; Altun, Y.; Guven, G.; J. Chem. Eng. Data 2014, 59, 4015. 
8. Dogan, A.; Kilic, E.; Anal. Biochem. 2007, 365, 7.

9. Gharib, F.; Jabbari, M.; Farajtabar, A.; J. Mol. Liq. 2009, 144, 5.

10. Jabbari, M.; Gharib, F.; Acta Chim. Slov. 2010, 57, 325.

11. Jabbari, M.; Gharib, F.; J. Solution Chem. 2011, 40, 561.

12. Jabbari, M.; J. Mol. Liq. 2015, 208, 5.

13. Pehrsson, L.; Ingman, F.; Johansson, A.; Talanta 1976, 23, 769.

14. Beltran, J. L.; Codony, R.; Prat, M. D.; Anal. Chim. Acta 1993, $276,441$.

15. Sanli, S.; Sanli, N.; Alsancak, G.; J. Braz. Chem. Soc. 2009, 20, 939.

16. Gans, P.; O’Sullivan, B.; Talanta 2000, 51, 33.

17. Cox, B. G.; Jedra, W.; Palou, J.; J. Chem. Soc., Dalton Trans. 1988, 733 .

18. Kriss, E. E.; Kurbatova, G. T.; Zh. Neorg. Khim. 1976, 21, 2368.

19. Wahlberg, O.; Acta Chem. Scand. 1971, 25, 1045.

20. Beck, M. T.; Nagypal, I.; Chemistry of Complex Equilibria; Ellis Horwood Limited: New York, 1990.
21. Berry, R. S.; Rice, S. A.; Ross, J.; Physical Chemistry; John Wiley \& Sons: New York, 1980.

22. Bronsted, J. N.; J. Am. Chem. Soc. 1922, 44, 877.

23. Guggenheim, E. A.; Philos. Mag. 1935, 19, 588.

24. Scatchard, G.; Chem. Rev. 1936, 19, 309.

25. Bretti, C.; de Stefano, C.; Foti, C.; Sammartano, S.; Vianelli, G.; J. Chem. Thermodyn. 2012, 44, 154.

26. Jabbari, M.; Zhiani, R.; Farajtabar, A.; J. Chem. Sci. 2015, 127, 1067.

27. Pitzer, K. S.; Activity Coefficients in Electrolyte Solutions, $2^{\text {nd }}$ ed.; USA CRC Press Inc: Boca Raton, 1991.

28. Bretti, C.; Foti, C.; Porcino, N.; Sammartano, S.; J. Solution Chem. 2006, 35, 1401.

Submitted: October 22, 2015 Published online: November 30, 2015 